\title{
A New Record of the Family Brachyceridae (Coleoptera: Curculionoidea) and a New Species, Desmidophorus hebes(Fabricius), in Korea
}

\author{
Ki-Jeong Hong*, Sangwook Park ${ }^{1}$ and Taewoo Kim²
}

Pest Risk Management Division, Department of Plant Quarantine, Animal, Plant \& Fisheries Quarantine \& Inspection Agency, Anyang, 430-016, Republic of Korea ${ }^{1}$ School of Agricultural Biotechnology, Seoul National University, Seoul, 151-742, Republic of Korea

${ }^{2}$ Invertebrate Research Division, National Institute of Biological Resources, Incheon, 404-708, Republic of Korea

\section{한국산 미기록과 턱바구미괘딱정벌리목, 바구미상과에 속한 무궁화턱바구미}

\author{
홍기정* 박상욱 $^{1} \cdot$ 김태우 ${ }^{2}$ \\ 농림수산검역검사본부 식물검역부 위험관리과, ${ }^{1}$ 서울대학교 농생명공학부, ${ }^{2}$ 국립생물자원관 무척추동물연구과
}

\begin{abstract}
The family Brachyceridae is reported for the first time in Korea and is represented by Desmodophorus hebes (Fabricius, 1781). A revised description, morphological photographs of adults, illustrations of genitalia, a key to the families of Korean Curculionoidea, and a key to the East Asian species of Desmidophorus are provided.
\end{abstract}

Key words: Desmidophorus hebes, Brachyceridae, New to Korea

초 록: 한국산 미기록과인 턱바구미과(Brachyceridae)(신칭)에 속한 Desmodophorus hebes (Fabricius) (무궁화턱바구미)(신칭)를 국내에서 처음 으로 분류학적으로 검토하였다. 이 종에 대한 재기재문, 성충사진, 진단형질 그림, 동아시아지역에 분포하는 Desmidophorus (턱바구미속)의 종 검 색키와 한국산 바구미상과(Curculionoidea)의 과(family) 검색키를 제공하였다.

검색어: 무궁화턱바구미(Desmidophorus hebes), 턱바구미과(Brachyceridae), 한국미기록

The family Brachyceridae apparently emerged in the middle Cretaceous. It has apomorphic state of characters as precoxal part of the prothorax shorter than the postcoxal one, connate elytra, secondarily thickened snout and true 8th sternite in male and plesiomorphic state of character as reduced tegmen to the group of Dryophthoridae, Curculionidae, Scolytidae, and Platypodidae (Legalov, 2006). Most of them are flightless because the elytra are grown together along the suture and the hind wings are vestigial. The larva live in the soil and feed on the roots of the

*Comesponding author: stpeters@korea.kr

Received May 21 2011; Revised July 62011

Accepted July 272011 host plant, and the adults feed on the leaves.

The subfamily Desmidophorinae which comprises genus Desmidophorus, was first proposed by Morimoto (1962) in the family Brentidae, based principally on the Brentid-Apionid type aedeagus and undeveloped proventriculus. Recently it was transferred to the subfamily Ocladiinae in the family Brachyceridae as a tribe based on the primitive features in the aedeagus, proventriculus and the larvae characters as antennal sensorium with conical, ogival or semiellipsoidal, not or hardly longer than wide, with collar-like structure at base, clypeus with two setae and a sensillum on each side and legs absent (Alonso-Zarazaga \& Lyal, 1999; Morimoto \& Kojima, 2006). 
There are special structure, mandibular scar on the mandibles of genus Desmidophorus, and the edge of the scar is always slightly raised above the adjoining surface of the mandible. This structure called mandibular scar serves as a support for a deciduous cusp, which normally breaks off soon after the emergence of the adult from the pupal chamber in the soil though persisting in a few individuals. The members of genus Desmidophorus Dejean, 1835 are widely distributed in Oriental region and are considered of the pests of bast fibre crops. There are more than 70 species in this genus in the Madagascar, Oriental region and East Asia. Among them, only 3 species (D. confucii Boheman, D. crassus Hubenthal, D. hebes (Fabricius)) of them are distributed in East Asian fauna (Chao \& Chen, 1980; Colonnelli, 2011).

In this paper, the family Brachyceridae is reported, represented by Desmodophorus hebes (Fabricius, 1781) for the first time in Korea. Redescription, morphological photographs of adult, illustration of genitalia, key to the families of Korean Curculionoidea and key to the East Asian species of Desmodophorus are provided. Specimens examined are deposited in Plant Quarantine Technology Center, Animal, Plant \& Fisheries Quarantine \& Inspection Agency, Suwon.

\section{Taxonomic Accounts}

\section{Family Brachyceridae Billberg, 1820 턱바구미과(신칭) Subfamily Ocladiinae Lacordaire, 1866 \\ Tribe Desmidophorini Morimoto, 1962}

\section{Genus Desmidophorus Dejean 턱바구미속(신칭)}

Desmidophorus Dejean, 1835: 296 (Type species: Curculio hebes Fabricius, 1781).

Botrobatys Chevrolat, 1842: 671 (Type species: Curculio fascicularis Olivier, 1791).

Trichosomus Chevrolat, 1881: 91 (Type species: Curculio senex Boheman, 1845).

Desmidophorinus Hubenthal, 1917: 111 (Type species: Desmidophorus aureolus Gyllenhal, 1837).

Pseudotrichosomis Hustache, 1925: 386 (Unjustified relacement name for Trichosomus Chevrolat).

Distribution. Korea, Japan (Ryukyu), China, Taiwan, Oriental region, Madagascar, Moluccas, New Guinea.
Diagnosis. Body oval closely covered with scales. Antennae geniculate. Mandibular scar serves as a support for a deciduous cusp, which normally breaks off soon after the emergence of the adult from the pupal chamber in the soil though persisting in a few individuals. Labial palpi 3-segmented. Front coxae separated. Prosternum before coxae deeply canalicuate.

Remarks. The members of this genus are pests of bast fibre crops. In the case of Desmidophorus crassus Hubenthal in Okinawa of Japan, adults are found from April/May to September, and feed on young branches of Hibiscus spp. They make oviposition holes into the pith of the branch and lay some eggs in a hole. Hatched larvae fall on the ground, crawl into the soil, and feed on the root of Hibiscus spp. Larvae feed on roots externally in the soil by making feeding groove and half burying the body in the groove. They make pupal cells in the soil in the late winter, and the pupal duration must be short. New adults have been observed in February and March. The mandibular appendages break off soon after emergence from the soil (Morimoto \& Kojima, 2006).

Desmidophorus hebes (Fabricius) 무궁화턱바구미(신칭) (Fig. 1)

Curculio hebes Fabricius, 1781: 174.

Desmidophorus morphosus Pascoe, 1888: 416.

Desmidophorus aterrimus Aurivillius, 1891: 220.

Redescription. Body length (excl. rostrum) $11 \mathrm{~mm}$, width $7.0 \mathrm{~mm}$. Body black, covered with black hairs, black hair tufts and light yellowish scales on short band at anterior margin and on apical part of elytra.

Head semiglobular; eyes weakly convex, partly concealed by ocular lobes at repose; rostrum robust and short, reaching shallow concavity between mesocoxae, punctation roughly and largely concave, forming irregular rows, basal part covered with thin and long decumbent yellowish scales; antennal insertions subterminal, antennal scrobes oblique from a little above the middle to the underside of base in lateral view, distant from eyes at base; antennae with 7 segments in funicle, 1st segment much longer than its width, funicle with proportions in length from basal constriction from 1st segment to 7 th one as 29: 22: 20: 18: 14: 12: 13, 5th and 6th segments as long as their width respectively, 7th segment shorter than its width (18), club compact, ovate and 


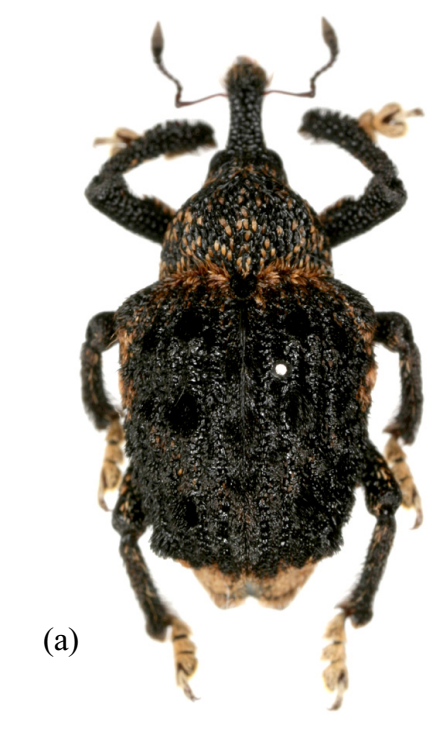

(b)

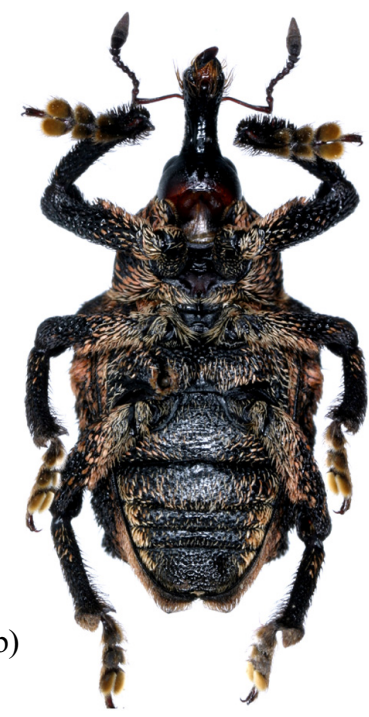

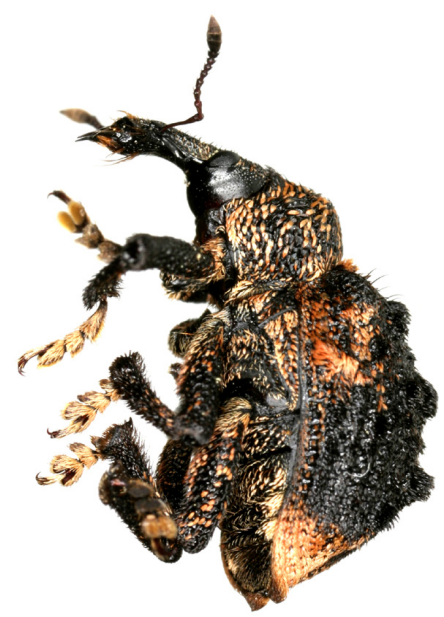

(c)
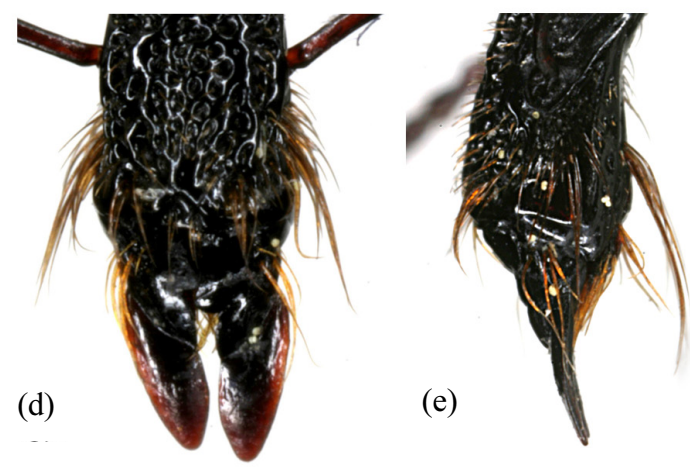

(f)
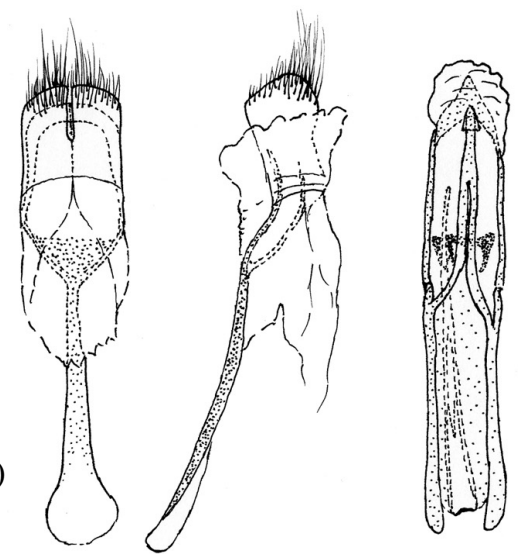

Fig. 1. Habitus and aedeagus of Desmidophorus hebes (Fabricius). a: dorsal side, b: ventral side, c: lateral side, d-e: deciduous appendage (cusp) on mandibles, f: male genitalia (tegmen and cap-piece, dorsal (left); tegmen and cap-piece, lateral (middle); aedeagus, dorsal (right)).

acuminate apically; mandibles move almost in a horizontal plane and occlude medianly, triangular, slender and more than twice as long as basal width dorsally, with median sharp tooth, dorsal cutting edge almost straight to base on left mandible, arcuate to base on right mandible, with deciduous appendage conspicuous on both mandibles; maxillary sinus weakly narrowed basally; maxillae with galea and lacinia fused, with three segments in palpi; labial palpi three-segmented on anterior margin of prementum; postmentum slender, very narrow, tapered basally; tentorium with gular margins narrowly and shortly divaricate at apex.

Pronotum 1.5 times as wide as its length, nearly bell-shaped, narrowed anteriad, largely punctuated with yellowish widen scales and blackish narrowed scales, with decumbent black hairs at anterior part, with ocular lobes and short vibrissae. Scutellum narrow and long, nearly heart-shaped, concave, bluntly narrowed apically, covered with numerous brown scales.

Elytra 1.5 times as wide as pronotum, with distinctly blunt humeri, slightly narrowed apically, conjointly rounded at apex, with narrow and short light yellowish band each side of anterior margin which connected with lateral band reaching 6th interval, strial punctures large and quadrate, interstice narrow, with tiny and short black hair tufts; 3rd and 5th interstice with 3 large black hair tufts, 7th interstice with 2 tufts.

Legs robust, femora weakly clavate, not sulcate, toothed; tibiae flattened, denticulate externally, uncinate at inner apical corner and in male uncinate near outer apical corner from the keeled flange, the latter unci small and obtuse on fore and hind 
tibiae, sharp on middle tibiae; hind tibiae with enclosed oval bevel surrounded by sharp keel and densely setose inside; tarsi with third segment deeply bilobate, claws simple, free.

Prosternum deeply and U-shapedly concave between ocular lobes at anterior margin, pectoral canal deep, bare, bordered laterally with sharp carina in front of fore coxae, and terminate at shallow bare concavity between middle coxae on mesosternum; fore coxae as widely distant as middle coxae. Venter with 1st ventrite behind coxa as long as 2nd, and as long as 3rd and 4th combined, 1st suture deep, entire. 5th ventrite in female more convex in the middle and more concave each side than in male, shallowly concave in the middle of posterior margin in male and densely covered with erected yellowish hairs each side.

Male genitalia with 8th sternite undivided, crescent; 9th sternite ovate, lamellar; spiculum gastrale curved; aedeagus with dorsal plate, tegmen with large cap-piece, manuburium almost as long as apodeme.

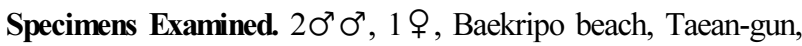
Chungnam province, 28. v. 2006, TW Kim; $10^{x}, 4$ 우 우, ditto, 24. vi. 2006, TW Kim.

Distribution. Korea (Central - New record), China (Shanghai, Jiangsu, Zhejiang, Jiangxi, Hubei, Hunan, Guangdong, Guangxi, Sichuan, Yunnan), Philippines, Vietnam, Thailand, Bangladesh, India, Pakistan.

Host Plants. Hibiscus syriacus and H. mutabilis (Chao \& Chen, 1980).

Biological Notes. Larvae are primarily feeding roots in soil and adults oviposit in stems (Pandit et al., 1986).

\section{Key to the family of Korean Curculionoidea}

(modified from Morimoto et al., 2006)

1. Labrum distinct, delimited posteriorly by clypeo-labral suture; maxillary palpi elongate, flexible Anthribidae

- Labrum obliterated; maxillary palpi short, inflexible 2

2. Rostrum absent, with pleurostomal sinus shallow; postcoila shallow and simply lying on the anterior margin of hypostoma for receiving conical postartis of mandible; hypostomal process absent; mandibles not produced nor laminate at laterobasal corner, with lateral depression or sulcus for receiving prominence of pleurostomal margin
- Rostrum present, mostly slender, with pleurostomal sinus deep; postcoila various in position, lying at antero-interior margin, a little behind, or on the anterior margin of hypostoma; hypostomal process present except for Attelabidae; mandibles with subspherical to spherical postartis, without lateral sulcus

3. Tarsi with 1st segment not longer than the 2nd and 3rd segments combined; gular with posterior tentorial arms broadly conglutinate to the divaricated part of gular sutures, which extending anteriorly and continued to subgenal sulci in parallel to exterior margin of hypostomal sinus when viewed ventrally; paracoila located at the bottom of hypostomal sinus Scolytidae

- Tarsi with 1st segment longer than the rest combined; gular with posterior tentorial arms broadly conglutinate with sheet-like extension of hypostoma from paracoila, and thus the pregular sutures continued anteriorly to hypostomal margin at the bottom of hypostomal sinus on each side of postmentum when viewed ventrally; paracoila translocated interiorly from bottom of hypostomal sinus

Platypodidae

4. Ventrites similarly articulated at least from the 1 st to 4 th, 5 th ventrite deeply articulated with 4 th at base in general $\cdots . .5$ - 1st and 2nd ventrites fused together, 1st suture weak, 3rd to 5 th ventrites deeply and similarly articulated to each other at base, 2nd and 5th ventrites often longer than each 3rd and 4th ventrites

5. Tibiae mucronate in both sexes, uncinate in male; front tibiae serrate on the ventral margin; claws connate; mandibles short, pincer shaped; abdomen with 1st to 4th ventrites conglutinate together, 1 st to 6 th tergites conglutinate together; female 8th sternite without speculum ventrale; prementum almost as wide as postmentum, labial palpi inserted into cavities on the ventral surface of prementum, 2- or one-segmented or often reduced to a sensory pore; preoral cavity divided by a narrow transverse bridge; metendosternite with lateral arms rounded and flat Attelabidae

- Tibiae neither uncinate nor mucronate, not serrate on the ventral margin; claws free; mandibles flat, toothed on inner and outer margins; abdomen with 1st and 2nd ventrites fused, the rest sternites and tergites freely articulated; female 8th sternite always with speculum ventrale; postmentum 
widening apically and embracing prementum in a deep concavity at apex, labial palpi mostly 3-segmented, inserted at antero-lateral margin of prementum; preoral cavity without transverse bridge; metendosternite with lateral arms more or less projected and trough-shaped

Rhynchitidae

6. Prementum very small, deeply retracted into oral cavity and invisible externally; antennae inserted behind the middle or close to base of rostrum, funicle with 6 or fewer segments, basal segment of club often smooth; claw segment of tarsi mostly produced at dorsal and ventral apices and so curved between claws as to embrace the globular base of claws; male 7 th tergite forming pygidium Dryophthoridae

- Prementum of normal size and freely visible from ventral side in front of postmentum; antennae inserted elsewhere between base and apex, funicle often 7-segmented; claw segment of tarsi not embrace the simple base of claws at apex in general; male 8th tergite partly exposed behind 7 th at apex in general 7

7. Trochanters unusually elongate, separating femora distantly from coxae 8

- Trochanters small, allowing femora to approach closely coxae

8. Antennae orthocerous; maxillary palpi 2-segmented; labial palpi one-segmented; body often broadest behind the middle Apionidae

- Antennae geniculate; maxillary palpi 3-segmented; labial palpi 2-segmented; body mostly broadest on humeri

Nanophyidae

9. Proventriculus not developed, with 8 or 16 rows of setae; male aedeagus with tectus (dorsal plate), tegmen with large and bilobate cap-piece 10

- Proventriculus mostly developed, with 8 or 16 rows of blade-like sclerites with a few exceptions; male aedeagus mostly without tectus (except some genera of Erirhinini), tegmen at most with a pair of parameres $\cdots$... Curculionidae

10. Labial palpi minute, inserted in deep pits on inner surface behind apical margin; rostrum porrect, often slender, without definite scrobes; body slender Brentidae - Labial palpi of normal size, not inserted in pits; rostrum robust, with definite antennal scrobes; body robust

\section{Key to the subfamilies and tribes of family Brachyceridae}

(modified from Morimoto \& Kojima, 2006)

1. Rostrum in repose not retractable; deciduous processes on mandibles present

Brachycerinae

- Rostrum in repose retractable in prosternal furrow; deciduous processes on mandibles present or absent

Ocladiinae $\cdots \cdot 2$

2. Deciduous processes on mandibles absent …..... Ocladiini

- Deciduous processes on mandibles present ${ }^{*}$ Desmidophorini

\section{Key to the species of genus Desmidophorus from East Asia}

(modified from Chao \& Chen, 1980)

1. Elytra with distinct median transverse band ……............ 2

- Elytra with indistinct median transverse band or without, mostly with bands on lateral sides. Body length (excl. rostrum) 7.0-13.8mm. Korea, China, Philippines, Southeast to South Asia D. hebes (Fabricius, 1781)

2. Elytra with median transverse band which connected to spot patterns; scutellum complete black, not concave. Body length (excl. rostrum) 9-11 mm. China (Southwestern), Oriental region

D. confucii Boheman, 1837

- Elytra without median band; scutellum covered with yellowish or brown hair-like scales, concave. Body length (excl. rostrum) 11-14mm. Japan (Ryukyu), Taiwan

D. crassus Hubenthal, 1917

\section{Literature Cited}

Alonso-Zarazaga, M.A. and C.H.C. Lyal. 1999. A World Catalogue of Families and Genera of Curculionoidea (Insecta: Coleoptera) (Excepting Scolytidae and Platypodidae). Entomopraxis, Barcelona. $315 \mathrm{pp}$

Aurivillius, C. 1891. Collection d'insectes formée dans l'Indo-Chine par M. Pavie consul de France au Cambodge (Suite). Nouvelles Archives du Muséum d'Histoire Naturelle (3)3: 205-224.

Billberg, G.J. 1820. Enumeratio insectorum in musaeo Gust. Joh. Billberg. Stockholm: Gaedelianis, [2] + 138 pp

Chao, Y. and Y. Chen. 1980. Coleoptera: Curculionidae(I). Economic Insect Fauna of China, Fasc. 20, Science Press, Beijing, China. $184 \mathrm{pp}$.

Chevrolat, L.A.A. 1842. Botrobatys. P. 671. In: D'Orbingny, C. (ed.). Dictionnaire Universel d'Histoire Naturelle. Vol. 2. C. Renard, 
Paris. 795 pp.

Chevrolat, L.A.A. 1881. Description de Curculionides de Zanguebar. Annales de la Société Entomologique de Belgique 25: 85-93.

Colonnelli, E. 2011. Brachyceridae, pp.182. - In I. Löbl \& A. Semetana (ed.). Catalogue of Palaearctic Coleoptera, Volume 7. Stenstrup, Apollo Books. 373 pp.

Dejean, P.F.M.A. 1835. Catalogue des coléoptères de la collection de M. le Comte Dejean. Deuxième edition. 4è livraison. Paris: Mequignon-Marvis \& fils, pp. 257-360.

Fabricius, J.C. 1781. Species insectorum exhibentes eorum differentias specificas, synonyma auctorum, loca natalia, metamorphosin adiectis observationibus, descriptionibus. Tomus I. Hamburgi et Kilonii: C.E. Bohnii, viii +552 pp.

Hubenthal, W. 1917. Die indomalaiischen Arten der Curculionidengattung Desmidophorus Schönherr. Entomologische Blätter 13(4-6): 103-123.

Hustache, A. 1925. Synopsis des curculionides de la faune malgasche. Bulletin de l'Academie Malgache (N.S.) 7: 1-582.

Lacordaire, T. 1866. Histoire naturelle des insectes. Genera des coléopères ou exposé méthodique et critique de tous les genres proposés jusqu'ici dans cet ordre d'insectes. Tome septième contenant les familles des curculionides (suite), scolytides, brenthides, anthribides et bruchides. [1866]. Paris: Librairie Roret. 620 pp.
Legalov, A.A. 2006. Phylogenetic reconstruction of weevil superfamily Curculionoidea (Coleoptera) using the SYNAP method. Biology Bulletin 33(2): 127-134.

Morimoto, K. 1962. Key to families, subfamilies, tribes and genera of the superfamily Curculionoidea of Japan excluding Scolytidae, Platypodidae and Cossoninae. Journal of the Faculty of Agriculture, Kyushu University 12: 21-66.

Morimoto, K. and H. Kojima. 2006. Larva of Desmidophorus crassus and the Systematic Position of Desmidophorini (Coleoptera: Curculionioidea). Esakia 46: 89-100.

Morimoto, K., H. Kojima and S. Miyakawa. 2006. Superfamily Curculionoidea: General introduction and family Curculionidae: Entiminae (Part 1): Phyllobiini, Polydrusini and Cyphicerini. The Insects of Japan, No. 3. Touka Shobo Co. Ltd., Fukuoka. 406 pp. Pandit, N.C., S.K. Pradhan and S. Chakravorty. 1986. Incidence, host susceptibility and natural population control of large black weevil Desmidophorus hebes - a new pest of bast fibre crop. Proceedings of a national symposium on pesticide residues and environmental pollution, Muzaffarnagar, India, 2-4, October, 1985, p. 233-239. (indirected)

Pascoe, F.P. 1888. Descriptions of some new genera and species of Curculionidae, mostly Asiatic. Part V. Annals and Magazine of Natural History (6)2(11): 409-418. 